\title{
Reduplication in Slavic and Baltic: loss and renewal
}

\author{
Henning Andersen
}

Received: 2 January 2008 / Accepted: 2 March 2009 / Published online: 12 November 2009

(C) The Author(s) 2009. This article is published with open access at Springerlink.com

\begin{abstract}
The exposition comprises three parts. Part 1 surveys the Indo-European reduplication patterns (RPs) that have been lost in Slavic and Baltic: the languages show little or no evidence of inherited RPs in present and perfect formations, and in intensive verbs (Sect. 2.1), but some vestiges of reduplication in nouns can be identified (Sect. 2.2). Part 2 describes innovated RPs in the Slavic verb; they can be posited on the basis of scanty evidence that has survived the Late Common Slavic loss of coda obstruents. Part 3 describes Baltic innovations reflected in Lithuanian: reduplicative root formations (Sect. 4.1), several minor lexicalized RPs (Sect. 4.2.), and the para-lexical part of speech called eventives (Sect. 4.3). Their content categories, types of expression, patterns of iconicity, and grammatical function are analysed and exemplified in some detail. It is suggested that formations such as these may form the natural background for the creation of new patterns of morphological expression including patterns of reduplication.
\end{abstract}

Keywords Aspect $\cdot$ Elative $\cdot$ Eventive $\cdot$ Iconicity $\cdot$ Intensive $\cdot$ Onomatopoeia

\section{Introduction}

\subsection{Preamble}

Like several other Indo-European language groups, Slavic and Baltic provide examples of the diachronic development of reduplication patterns (RPs). In this paper I will describe a few such patterns. Some of these were inherited from IndoEuropean and have been lost in Slavic and Baltic. They can be identified only 
through comparative and internal reconstruction (Sect. 2). Some RPs appear to have been innovated in Slavic (Sect. 3), and some have developed in Lithuanian, which will be proxy for the Baltic languages in this paper. Of these, some are minor patterns, but there is also a set of still productive techniques, including total and partial reduplication, which are used to form more or less expressive 'eventive' predicates in Lithuanian (Sect. 4).

These diachronic and synchronic examples provide some insight into aspects of the development of reduplication.

First, the expression side of reduplicants. Slavic and Baltic languages offer suggestive evidence, but no positive evidence, for the commonly assumed idealized life cycle of RPs in (1). Where such a development can be posited (Sect. 3) it must have been eliminated by haplology and regular sound change. But in other cases of loss, the data from both language groups illustrate the way reduplicants become opaque through analogical or assimilative change once a RP has lost its productivity. Stage 5 represents a variety of possible opaque reduplicant reflexes which may be the point of departure for comparative or internal reconstruction (Sect. 2.2.1; Sect. 3). By contrast, the account of Stage 1 reduplication that is exemplified in Sect. 4.3 is suggestive of forerunners of RPs that have not yet been codified let alone grammaticalized.

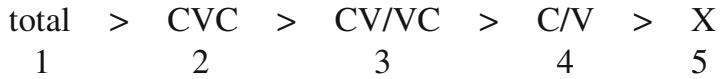

Secondly, the content side of reduplication. It can be assumed that all grammaticalized or lexicalized reduplication originates in expressive total or partial reduplication, which is subsequently codified as a technique for word formation or inflection. The types of reanalysis involved in such diachronic developments are nowhere to be observed in the history of the Slavic and Baltic languages, but can be posited as the basis of the RPs in Sect. 4.2.

Thirdly, the relation between content and expression. This is presumably always iconic in origin, but it commonly loses in iconicity as an expression or expression pattern is lexicalized or morphologized. The exposition in Sect. 4.3 will distinguish types and levels of iconicity which may be generally useful in an analytic approach to the development of RPs.

\subsection{Reconstructed stages of Slavic and Baltic languages}

To save space exemplification from Slavic will be limited to Old Church Slavonic, the language of the oldest Slavic text corpus, and a few of the modern languages. More extensive exemplification can be found in etymological dictionaries (e.g. Vasmer 1952-1957; Trubačev 1973-). Similarly, for Baltic, the focus will mainly be on Lithuanian (see further Fraenkel 1962-1965).

Two prehistorical stages of Slavic will be referred to, the shallow reconstruction, traditionally called Proto-Slavic, which is here called Late Common Slavic, and the earliest reconstructible stage of Slavic, here labeled Proto-Slavic (cf. Andersen 
1986, 1993/1998). For Baltic forms, the earliest reconstructible stage is labeled Proto-Baltic.

In some instances, comparison of Proto-Slavic or Proto-Baltic forms with their Proto-Indo-European etyma reveals that presumably inherited forms changed prior to the reconstructed Proto-Slavic or Proto-Baltic stages. In such instances it is useful to posit Pre-Proto-Slavic, respectively Pre-Proto-Baltic, forms.

Besides Proto-Indo-European, earlier stages that can be reconstructed by internal comparison are referred to as Pre-Proto-Indo-European.

All these prehistorical stages come into play in Sect. 2.

Attested forms will be cited in italics. Reconstructed forms will be cited without asterisks, but in normal roman font. Their labeling will indicate that they are reconstructed. ${ }^{1}$

\section{Loss}

Both Slavic and Baltic lack the RPs reconstructed for Proto-Indo-European, but have some reflexes of them in verbal formations (Sect. 2.1) and in nouns (Sect. 2.2).

Three RPs are reconstructed for the PIE verb. $\mathrm{C}_{1} \mathrm{~V}_{\mathrm{x}}$-reduplication occurs in certain verbs in Present tense (Imperfective aspect) forms (Sect. 2.1.1). In addition, $\mathrm{C}_{1} \mathrm{~V}_{\mathrm{x}}$-reduplication is productive in the Perfect (Stative aspect) (Sect. 2.1.2). Besides, both $\mathrm{C}_{1} \mathrm{eC}_{2}$-and $\mathrm{C}_{1} \mathrm{~V}_{1} \mathrm{C}_{2}$-reduplication are productive in the formation of Intensive verbs (Sect. 2.1.3).

Two RPs are attested in nouns, PIE $C_{1}$ e-reduplication (Sect. 2.2.1) and $C_{1} V_{1} C_{2}$ reduplication (Sect. 2.2.2).

\subsection{Reduplication in the verb}

The two $\mathrm{C}_{1} \mathrm{~V}_{\mathrm{x}}-\mathrm{RPs}$ can both be reconstructed with a vowel alternation in the reduplicant (hence the $\mathrm{V}_{\mathrm{x}}$ ), presumably conditioned by the Pre-PIE place of accent, which remains reflected in the root vocalism of the attested forms (e.g. Pre-PIE $\mathrm{C}_{1} \mathrm{e}-\sim \mathrm{C}_{1}$ é- $>\mathrm{PIE} \mathrm{C}_{1} \mathrm{i}-\sim \mathrm{C}_{1} \mathrm{u} \sim \mathrm{C}_{1}$ é-); see the examples in (2), (5). In the daughter languages this alternation has been leveled by the generalization of one reduplicant shape $\left(\mathrm{C}_{1} \mathrm{e}-\right.$; PIE e $>$ Ved. $\left.a\right)$ or the other $\left(\mathrm{C}_{1} \mathrm{i}-\right.$; the presumable $\mathrm{C}_{1} \mathrm{u}$ - alternant has been lost); see the Greek examples in (2), (5); Gamkrelidze and Ivanov (1984, p. 220); Rasmussen (1984/1988, p. 125, 1997, p. 252); Kulikov (2005, p. 449).

$\mathrm{C}_{1} \mathrm{eC}_{2}$-reduplication in Intensive verbs is accompanied by o-vocalism in the root (6) and by elision of any root-final laryngeal, as seen in (6.a) (where a syllabic PIE laryngeal regularly yields Ved. $i$ ).

\footnotetext{
${ }^{1}$ The following abbreviations are used: adj. (adjective), adv. (adverb), ChS (Church Slavonic), Cz. (Czech), d., dial. (dialectal), Eng. (English), Fi. (Finnish), Gk. (Greek), Gm. (German), Ir. (Irish), Lat. (Latin), LCS (Late Common Slavic), Li. (Lithuanian), Lv. (Latvian), n. (noun), OCS (Old Church Slavonic), OE (Old English), OCz. (Old Czech), OHG (Old High German), ON (Old Norse), OPr. (Old Prussian), OR (Old Russian), P (Polish), PB (Proto-Baltic), PIE (Proto-Indo-European), P (Polish), PrePB (Pre-Proto-Baltic), Pre-PIE (Pre-Proto-Indo-European), Pre-PS (Pre-Proto-Slavic), PS (Proto-Slavic), R (Russian), RChS (Russian Church Slavonic), RP (reduplication pattern), SBC (Serbian-BosnianCroatian), Sk. (Slovak), Skt. (Sanskrit), Ved. (Vedic Sanskrit), W (Welsh).
} 


\subsubsection{Present}

Of the three RPs that are reconstructed for the PIE verb, only one is reflected in Slavic and Baltic, viz. the $\mathrm{C}_{1} \mathrm{~V}_{\mathrm{x}}$-reduplication that characterizes the Present tense (Imperfective aspect). Furthermore, it is attested only in two verbs, PIE d $\mathrm{h}^{\mathrm{h}} \mathrm{h}_{1^{-}}$'put' and PIE deh $_{3^{-}}$'give' (2).

(2) (a) PIE $d^{\mathrm{h}} \mathrm{eh}_{1^{-}}$'put'. PIE d $\mathrm{d}^{\mathrm{h}} \mathrm{d}-\mathrm{d}^{\mathrm{h}}$ éh $\mathrm{h}_{1}$-ti.3sG, $\mathrm{d}^{\mathrm{h}} \mathrm{e}-\mathrm{d}^{\mathrm{h}} \mathrm{h}_{1}-$ ṇti.3PL. Ved. dá-dhāti.3sG, dá-dh-ati.3PL. GK. tí-thè-si.3sG, ti-thé-āsi.3PL.

(b) PIE deh $_{3^{-}}$'give'. PIE di-déh ${ }_{3}$-ti.3sG, dé-dh ${ }_{3}-n$ ti.3PL. Ved. dá-dā-ti.3sG, dá-d-ati.3PL. Gk. dí-dō-si.3sG, di-dó-āsi.3PL.

The Slavic cognates of these show traces of reduplication in the Present tense and derived forms (Vaillant 1966, pp. 303, 447), see (3). In 'put', the Present tense was thematicized in several regional variants based on the Present-tense plural stem (i) Pre-PS de-d-je/o or, with the Aorist (Infinitive) stem replacing the reduplicant, (ii) PS dē-d-e/o, or based on the Aorist stem (iii) PS dē-je/o- or (iv) PS dē-ne/o-; see (3.a). In 'give', the reduplicant in the Present plural stem has been replaced with the Aorist (Infinitive) stem PS dā- (i.e. de-d- > dā-d-); see (3.b).

In Baltic, too, the two verbs show evidence of reduplication in the Present tense and derived forms (Stang 1966, pp. 310, 334), see (4). In 'put', the presumable PIE (and Pre-PB) plural stem has been generalized and thematicized as a (PB) a-stem; see (4.a). In 'give', the reduplicant has been replaced with the Aorist (Infinitive) stem, PB dō- (i.e. de-d- > dōd-).

(3) (a) OCS dě-ti.INF 'put', dežd-o.1sG, dežd-e-tŭ.3sG, dežd-o-tŭ.3PL. Pre-PS dē-tei.INF, di-dē-mi, di-dē-ti, de-d-inti, cf. (2.a). Thematicized based on the Present plural stem (i) PS de-d-jō-m, de-d-je-ti, de-d-ja-nti (with $/ \mathrm{dj} />$ OCS $/ \check{\mathrm{z} d} /$, SBC dial. ded èm) or (ii) with the Aorist stem replacing the reduplicant PS dē-d-ō-m (SBC dial. djëdèm), or based on the Aorist stem (iii) PS dē-j-̄̄-m (OCS dě-j- $Q$, R dial. déju) or (iv) PS dē-n-ō-m (SBC djënēm, R dénu).

(b) OCS da-ti.INF 'give', da-mŭ.1sG, das-tŭ.3sG, dad-ę-tŭ.3Pl. Pre-PS dōtei.INF, di-dō-mi, di-dō-ti, de-d-inti, cf. (2.b). Athematic as PS dātei.INF, dād-mi $(\mathrm{dm}>\mathrm{m})$, dād-ti $(/ \mathrm{dt} />/ \mathrm{st} /)$, dād-inti.

(4) (a) Li. dé-ti.INF, ded-ù.1SG, dẽ d-a.3sG-PL 'put'. Pre-PB dē-tei.INF, di-dēmi, di-dē-ti, de-d-inti, cf. (2); (thematicized as) pre-Li. dē-ti, de-d-ō, ded-a-.

(b) OLi. duo-mi.1sG, duo-si.2sG, duos-ti.3, duod-i.IMPV, duod-as.PRs.PCPL 'give'. OPr dā-se.2sG, dās-t.3. Pre-PB dō-ti.Inf, di-dō-mi, di-dō-ti, dedinti (cf. (4.a); reduplicant replaced with Infinitive stem (de-d- > dōd-, then $\mathrm{dm}>\mathrm{m}$, ds $>\mathrm{s}$, dt $>\mathrm{st}$ ); later thematicized as Li. dúoti.INF, dúodu. 1sG, dúod-a.3. 


\subsubsection{PIE perfect}

There are no surviving examples of the PIE Perfect RP (5) in either Slavic or Baltic. But both language groups have a number of stative verbs with reflexes of PIE o-grade or zero grade root vowel pointing to the former existence of the Perfect (Stative).

(5) (a) PIE genh $1^{-}$'come to be, be born'. PIE ge-gōn-a.1sG, ge-gn-men.1PL. Gk. gé-gon-a.1sG 'am', (Hom.) gé-ga-men.1PL.

(b) PIE weid- 'see'. PIE (wu-)wóid- (SG), (wé-)wid- (PL) 'know'. Ved. véd-

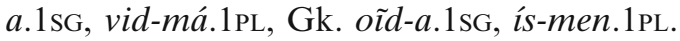

Slavic examples of such statives are OCS gor-i-tŭ 'burns', PS gar-1-; bol-i-tŭ 'hurts',

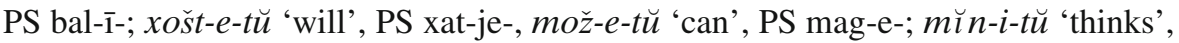
PS min-1-; $b \breve{u} d-i-t \breve{u}$ 'is awake', PS bud-1-. Some Baltic stative verbs with reflexes of PIE o-grade or zero grade which are likely reflexes of the erstwhile PIE Perfect: Li. gar-e-ti.INF-gãr-i.3SG-PL 'burn; intr.' stov-e-ti-stóv-i 'stand', nor-e-ti-nór-i 'will', gale-ti-gãl-i 'be able', min- $\dot{e}-t i-m i n-i$ 'remember', gird-e-ti-gird-i 'hear', tur- $\dot{e}-$ $t i-t u ̀ r-i$ 'have'. But there are no traces of reduplication in these verb types.

One single Slavic verb has a unique desinence that can be identified with the PIE

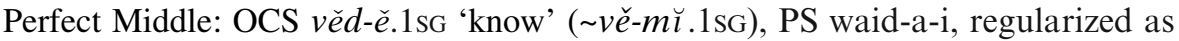
PS waid-mi. But it, too, shows no traces of reduplication; cf. (5.b).

\subsubsection{PIE intensive verbs}

The $\mathrm{C}_{1} \mathrm{eC}_{2}$-reduplication in PIE Intensive verbs is accompanied by o-vocalism in the root (6) and by elision of any root-final laryngeal, as seen in (6.a) (where a syllabic PIE laryngeal regularly yields Ved. $i$ ). The velar $\mathrm{C}_{1}$ is palatalized before $* e$ in the reduplicants of (6.a), (6.c).

(6) (a) PIE kerh- 'remind', ker-kor-. Ved. car-kar-mi.1sG 'commemorate' (cf. s-aor. $a-k \bar{a} r i-s-a m$ ).

(b) PIE $\mathrm{d}^{\mathrm{h}} \mathrm{er}$ 'support', $\mathrm{d}^{\mathrm{h}} \mathrm{er}-\mathrm{d}^{\mathrm{h}}$ or-. Ved. dár-dhar-și.2sG 'support strongly'.

(c) PIE ghen-'strike', $\mathrm{g}^{\mathrm{h}} \mathrm{en}-\mathrm{g}^{\mathrm{h}}$ on-. Ved. jan-ghan-ti.3sG 'strikes violently'.

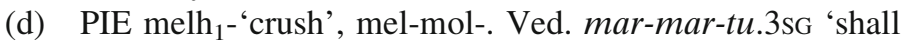
crush'.

A number of Slavic and Baltic verbs can be identified with the PIE Intensive formation. These verbs have o-vocalism and are semantically likely to be earlier Intensives. But they have the regular Slavic and Baltic laryngeal reflex (vowel length and acute accent) and show no signs of having had $\mathrm{C}_{1} \mathrm{eC}_{2}$-reduplication; see (7), (8). 
(7) (a) R kolót' 'break, stab', PS k'āl-tei, PIE kolh $2^{-}$.

(b) R borót'=sja 'fight', PS b ${ }^{1}$ ār-tei, PIE $\mathrm{b}^{\mathrm{h}}$ orh-.

(c) R porót' 'rip; flog', PS pāâr-tei, PIE perh $_{3}{ }^{-}$.

(8) (a) Li. kálti 'forge, strike', PB k'āl-tei, PIE kelh $2^{-}$.

(b) Li. bárti 'scold', PB b ār-tei, PIE b ${ }^{\mathrm{h}}$ erh-.

(c) Li. kárti 'hang', PB k'ār-tei.

\subsection{Nouns}

Two RPs are reconstructed for PIE nouns, $\mathrm{C}_{1} \mathrm{e}$-reduplication and $\mathrm{C}_{1} \mathrm{VC}_{2}$-reduplication. Examples of the former are widely attested, but have long since been

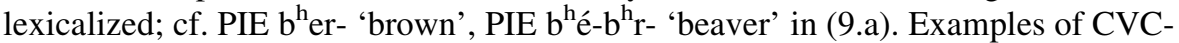
reduplication have the appearance of being less firmly established and more clearly onomatopoeic; cf. PIE? pel- onomatopoeic, pre-PS, pre-PB pel-pel- 'quail' (10.f); they appear to be younger.

\subsection{1 $C_{1}$ e-reduplication}

In each of the language groups, about a dozen nouns bear witness to the PIE $\mathrm{C}_{1} \mathrm{e}-$ $\mathrm{RP}$; examples in (9).

Among the Slavic examples, a few have retained initial Ce-. In some, the reduplicant vowel has been replaced, at least dialectally, with PS /a/, LCS /o/; see (a), (c), (f), (k). In some, the reduplicant is identical to a common prefix (PS pa- or pā-, LCS po-, pa-); see (e), (f). In one, the reduplicant vowel is a long vowel (reflex): (i).

Some of the Baltic examples in (9) have retained initial Ce-. In a few, the reduplicant vowel has been replaced, at least dialectally, with $\mathrm{PB}, \mathrm{Li}$. /a/ or /i/; see (a), (d), (e), (g) (h). In some lexemes, the reduplicant vowel has been replaced with a diphthong; see (c), (i), (j). In one etymon the reduplicant has reflexes of a long vowel, PB /ê/ or /ā/; cf. (i).

(9) (a) OR bebrŭ, bobrŭ 'beaver', R bob'ór. PS be-br-a- ( ba-). Li. bẽbras 'beaver', d. babras, Lv. bebrs, OPr. bebrus 'beaver'. PB be-br-a( ba-). PIE b ${ }^{\mathrm{h}}$ er- 'brown', $\mathrm{b}^{\mathrm{h}}$ é-b ${ }^{\mathrm{h}} \mathrm{r}-$. Cognates in Skt., OHG, Lat.

(b) Li. dedervine 'eczema', La. dedere. PB de-der-. PIE der- 'flay'. Cognates in Skt., W, OE, OHG.

(c) R gógol' 'goldeneye Bucephala clangula', P gogół. PS ga-gal-i- (<ge-). Li. gaĩgalas 'drake', OLi. giegals 'diving duck', Lv. gaigals 'sea-gull', OPr. gegalis 'diving duck'. PB ge-gal-a- ( gai-). PIE gh el- 'sing, speak', g'é-gh ol-. Cognates in ON, Eng.

(d) Li. kãklas 'neck', Lv. kakls. PB ka-kl-a- (< ke-), cf. Fi kaulas 'neck'. PIE k ${ }^{\mathrm{w}} \mathrm{el}-$ 'turn', $\mathrm{k}^{\mathrm{w}} \mathrm{e}-\mathrm{k}^{\mathrm{w}} 1-$ ' wheel'. Cognates in Skt., Gk., OE; OPr. kel-a-n 'wheel', OCS kolo-kolesa, PS kal-es/as-, cf. OHG hals, PIE $\mathrm{k}^{\mathrm{w}} \mathrm{ol}-\mathrm{S}-\mathrm{O}-$. 
(e) R páporotnik 'fern', $\mathrm{P}$ paproć, SBC paprat. PS pā-part-i-, nominal prefix PS pā- (< pe-). Li. papártis, papartis 'fern', Lv. paparde. PB pa-part-i- (< pe-). PIE per- 'fly'. Cognates in OHG, Ir., Li., Lv., Skt.

(f) R pépel, d. pópel. 'ashes', OCS pepelŭ, popelŭ. PS pe-pel-a ( pa-). PIE pelh ${ }_{1}$ ' 'burn; intr.'. Cf. Li. pelenaĩ, La. pèlni, OPr. pelanne 'ashes'.

(g) R téterev 'woodcock, black grouse Tetrao tetrix', OR teterevı̆. PS te-ter-w-i-. Li. tẽtervinas 'black grouse', Lv. teteris, OPr. tatarwis. PB te-ter-w-. PIE té-tre-. Cognates in ON, Gk., Skt., Lat.

(h) Li. titilvis 'sand-piper', Lv. stidilbis. PB ti-til-w- (< te-). Cf. Li. tilvikas 'snipe', PB til-w-i-ka-.

(i) OR věverica 'squirrel; ferret'. PS wē-wer-1̄-. Li. voverè 'squirrel; ferret', d. véveris, d. vaivere, Lv. vãvere, OPr. weware 'squirrel'. PB we-wer- ( wē- $\sim$ wā- $\sim$ wai-). PIE wer- 'bend'. Cognates in OE, $\mathrm{OHG}, \mathrm{W}$, Iran.

(j) Li. vievesà 'poultry louse'. PB wai-wes-ā- (< we-). PIE wes- 'louse; thistle'. Cf. Li. usnis 'thistle', LCS vǔš 'louse', PS ux-i-.

(k) R xoxól 'shock of hair, tuft, crest', Sk. kochol. PS xa-xal-a-. Cf. Lv. cekuls 'crest, tuft', OPr. kekulis 'Badelach'. PB ke-kul-.

(1) R d. zegzíca 'cuckoo', OR žegǔžulja, P gżegżółka, Cz. žežhule. LCS žegŭza. PS ge-guz-1̄-. Li. gegùžè 'cuckoo', Lv. dzeguze, OPr. geguse. PB ge-guž-iā-. PIE g $\mathrm{ug}^{\mathrm{h}}$ - onom., g é-g ${ }^{\mathrm{h}} \mathrm{ug}^{\mathrm{h}}$-. Cognates in ON, OHG, OE.

\subsection{2 $C_{1} V_{1} C_{2}$-reduplication}

A handful of Slavic and Baltic nouns attest to the PIE $C_{1} V_{1} C_{2}-R P(10)$. Here, as in Sect. 2.2.1, the reduplicants have become opaque, most of them through regular sound change, but some through replacement of the reduplicant vowel and consonant dissimilation; see (10.f-g). A few of those with o-vocalism have counterparts in other IE languages, but may not be of PIE date; cf. PS gal-gal-a- (10.b), probably related to the verb formations in Sect. 3.

(10) (a) R buben 'drum', OR bubonŭ, P bęben. PS bun-bun-a-. Cf. Li. bambeti 'grumble'.

(b) R glagól 'verb', OCS glagolŭ 'speech; word, verb'. PS gal-gal-a-; cf. R gólos 'voice', PS gal-s-a-. PIE ghel- 'speak'. Cf. (11.a).

(c) R kólokol 'bell', ChS klakolŭ. PS kal-kal-a-; cf. Skt. karkarí'musical instrument'.

(d) Li. murmùlis 'grumbler', Lv. mulmulis, mulmis 'stutterer'. PB mulmul-i-, cf. Li. murmeti 'mutter'.

(e) R prápor 'banner', OR poroporŭ, $\mathrm{P}$ proporzec, $\mathrm{ChS}$ praporŭ, $\mathrm{SBC}$ praporac 'jingle-bell'. PS par-par-a-. PIE per- 'fly'.

(f) $\mathrm{R}$ pérepel 'quail', OR perepelŭ, $\mathrm{P}$ przepiór. PS per-per-a-, per-pel-a(< pel-pel-a-). Li. piepala 'quail', La. paipala, OPr. penpalo 'quail', pepel 'bird'. PB pel-pel-ā- ( pai-). PIE? pel-pel- imitative. 
(g) Li. vieversỹs 'lark', OPr. werwirsis. PB wer-wer-s-ia- ( wai-). PIE wer- 'bend'.

\subsection{Discussion}

The idealized progression in (1) suggests one can speak of the 'apparent relative age of RPs'-a CV-pattern (Stage 3) would appear to be younger than a CVC-pattern (Stage 2). But in fact, this is only one of several indicators of relative age that can be exploited in diachronic work.

For instance, the $\mathrm{C}_{1} \mathrm{~V}_{\mathrm{x}^{-}}$RP in the PIE Present tense (Imperfective aspect) appears to be older than the similar pattern in the Stative: the former is unproductive, the latter is productive; the former is lexically limited, whereas the latter applies in several Perfect (Stative) formations in Sanskrit and across the board in Greek.

The two $C_{1} V_{x}-R P s$ (Stage 3) appear younger than the $\mathrm{C}_{1} \mathrm{eC}_{2}$ - reduplication (Stage 2 ). It is quite likely that the $\mathrm{C}_{1} \mathrm{~V}_{\mathrm{x}}$ - RPs at one time were derivational, though in the attested languages they index obligatory, grammatical categories; the Intensive category of the $\mathrm{C}_{1} \mathrm{eC}_{2}-\mathrm{RP}$, by contrast, is facultative, derivational.

Turning to Slavic and Baltic, one can note that traces of PIE RPs have been preserved better in nouns than in verbs. The reason for this disparity is very likely that in the formation of nouns, both CV-and CVC- RPs have been meaningful in the formation of stems, whereas in verbs, the RPs-whatever their original function-became ancillary to other expressions of the relevant grammatical categories, that is, reduplication became functionally secondary to other expressive means and reduced to the status of concomitant morphophonemic indexes. This is true of the Present (Imperfective) forms, which had the same desinences as verbs without reduplication. And it is true of the Perfect (Stative) formation, which had its own distinctive desinences. As for the Intensive verbs, it actually is not certain that these verbs ever had CVC- reduplication in Slavic and Baltic.

The remnants of the Slavic and Baltic reduplicative nouns, although more numerous, suggest that the loss of productive reduplication is not recent. The many examples in these forms of a reduplicant vowel assimilated to the stem vowel, or of reduplications reinterpreted as productive prefixes surely did not give rise to the observed opacity of the reduplicants; they are thus different from the cases of 'strengthening' discussed by Hurch and Mattes (2006). On the contrary, when these surface changes occurred they were symptoms that the respective lexemes were no longer transparent. In both verbs and nouns, content reanalysis set the lexemes up for metanalysis that integrated the reduplicant with the stem. One can posit several rationales for such reanalyses. The most general of these is undoubtedly semantic change that dissociates the lexical meaning of the reduplicate from that of its base; e.g. Pre-PS ge-gal-i is reanalysed as simply 'goldeneye' and thereby dissociated from the base gal- 'sound, voice'. A dissociation can also result from sound change, such as the (satəm) assibilation $\left(\hat{g}^{\mathrm{h}}>\mathrm{z}\right)$ in the word for 'cuckoo', PIE $\mathrm{g}^{\mathrm{h}} \mathrm{e}-\mathrm{g}^{\mathrm{h}} \mathrm{u} \hat{g}^{\mathrm{h}}-$ $>$ Pre-PS ge-guz- > LCS žegŭz-, which effectively obliterated the onomatopoeic associations of the expression. A dissociation of a reduplicate from its base would 
occur whenever it became impossible to identify the base as a recurrent partial; e.g. Li. vievesà 'poultry lice', but no **ves- with similar content.

\section{Renewal in Slavic}

Slavic languages have innovated several minor RPs in the formation of verbs. None of these have retained their productivity into the historical period.

One of them is the Stage 1 (CVC-) pattern in (11). The verbs here are activity verbs, the first three being either denominal (11.a) or iterative (11.b), (11.c); the geographical limitation of the latter two to East Slavic suggests they are based on Baltic (substratum) etyma. The last, (11.d), may be an originally intensive verb; its root is o-grade like the verbs in Sect. 1.1.3 (7).

(11) (a) R dial. gologólit', OCS glagolati 'speak'. PS gal-gal-ā-/-ī-tei; cf. R glagol 'speech, verb' (10.b), R golos, PS gal-s-a- 'voice'. PIE $\mathrm{g}^{\mathrm{h}} \mathrm{el}$ - 'speak'. Cognates in ON, Eng.

(b) R dial. balabólit' 'talk'. PS bal-bal-1-tei. PIE b el- 'speak'; cf. Li. balsas 'voice', PB bal-s-a-. Cognates in Gm., Eng.

(c) $\mathrm{R}$ dial. torotórit' 'talk'. PS tar-tar-1-tei; cf. Li. tar-ý-ti 'speak'.

(d) Cz. plapoláti 'be aflame', ChS plapolati. PS pal-pal-ā-tei; cf. OCS polěti 'burn', PS pal-ē-; R d. pólym’a, OCS plamę 'flame', PS pal-men-.

The two other RPs are onomatopoeic in origin; it is not surprising therefore, that a few of these verbs have parallels in other IE languages. The verbs in (12) and (13) have roots ending in a liquid or nasal, which combined directly with stem formants, PS -â-, -je-/-a-. In the modern reflexes the original reduplicative structure has become obliterated by regular sound change.

(12) (a) Cz. krákorati 'cackle, croak', OP krokorać. PS kar-kar-ā-tei.

(b) RChS po-tortra-ti 'rumble', Sn trtráti. PS tur-tur-ā-tei.

(c) OR iz-moromra- 'gnaw'. PS mur-mur-ā-tei. Cf. Li. murm-e-ti, Cf. Lat., Gk.

(13) (a) OR tutnati 'resound', P tętnąć. PS tun-tun-ā-tei. Cf. Lat.

(b) OR gugnati 'growl', Sn gognjáti. OCS gogŭn-ivŭ 'with impeded speech'. PS gun-gun-ā-tei. Cf. Gk.

(c) OCz. kuknati 'rumble, mumble'. LCS kokŭnati. PS kun-kun-ā-tei.

(d) R d. xuxnat' 'blame, despise', Sn. hohnjati 'speak with a twang'. LCS xoxŭnati. PS xun-xun-ā-tei.

The verbs in (14)-(17) have roots ending in an obstruent. They have lost all appearance of reduplication in the modern languages. In their (superficial) LCS reconstructions they exhibit a remarkable repetition of the root vowel preceding the stem suffix (e.g. trep-e-ta-ti, drŭg-ŭ-ta-ti); functionally, this echo vowel is a (meaningless) interfix. Vaillant (1966) reconstructs these verbs as originally Stage 1 reduplications; e.g. 
pre-PS trep-trep-tā-tei, drug-drug-tā-tei. Simplification of the internal consonantclusters would yield a pattern of stem-internal rhyme reduplication, Stage 3; e.g. PS trep-ep-tā-tei, drug-ug-tā-tei. Later, the Common Slavic general loss of coda obstruents (except/s/) would produce the LCS pattern of interfixed echo vowels. Stage 4; e.g. trep-e-ta-ti, drŭg-ŭ-ta-ti). This account derives its plausibility first of all from the parallelism with the sonorant-final roots in (12)-(13) and secondly from the fact that some of the posited root-reduplication verbs contrast with unreduplicated ones, e.g. Pre-PS trep-trep-tā-tei vs. PS trep-ā-tei; see (14.c), (15.c), (16.a), (16.c). The examples in (14)-(17) are organized according to the interfix vowel.

(14) (a) R gogotát' 'cackle'. LCS gog-o-ta-ti, PS gag-ag-tā-tei.

(b) R klokotát' 'bubble, gurgle'. LCS klok-o-ta-ti. PS klak-ak-tā-tei.

(c) R kokotát' 'crackle'. LCS kok-o-ta-ti. PS kak-ak-tā-ti. Cf. R kókat' 'crack', PS kak-ā-tei.

(d) Sn. lopotáti 'stutter'. LCS lop-o-ta-ti. PS lap-ap-tā-tei.

(e) R skrobotát' 'scramble with feet', OP skrobotać 'scrape'. LCS skrob-o-ta-ti. PS skrab-ab-tā-tei.

(f) R xoxotát' 'laugh heartily'. LCS xox-o-ta-ti. PS xax-ax-tā-tei.

(15) (a) R lepetát' 'babble, prattle'. LCS lep-e-ta-ti. PS lep-ep-tā-tei.

(b) R svepetát' 'flit'. LCS svep-e-ta-ti. PS swep-ep-tā-tei.

(c) R trepetát' 'tremble, quiver'. LCS trep-e-ta-ti. PS trep-ep-tā-tei. Cf. $\mathrm{R}$ trepát' 'scutch; flutter', ChS trepati 'rap', PS trep-ā-tei.

(d) ChS xrepetati 'neigh', Sn. hrepetáti 'be hoarse', R d. xrepotat'. LCS xrepe-ta-ti. PS xrep-ep-tā-tei.

(16) (a) SBC dřktati 'tremble'. LCS drŭg-ŭ-ta-ti. PS drug-ug-tā-tei. Cf. LCS drŭg-a-ti 'tremble', PS drug-ā-tei; drŭž-a-ti 'tremble', PS drug-ē-tei.

(b) R roptát' 'murmur, grumble', ChS rŭpŭ-ta-ti. LCS rŭp-ŭ-ta-ti. PS rup-up-tā-tei.

(c) R toptát' 'trample', P deptat'. LCS tŭp-ŭ-ta-ti, dŭp-ŭ-ta-ti. PS tup-uptā-tei, dup-up-tā-tei. Cf. R tópat' 'tramp', PS tap-ā-tei. Cf. Gr. túpos 'stamp'.

(17) (a) R mečtát' 'dream'. LCS mǐč-̌̆-ta-ti. PS mik-ik-tā-tei. Cf. Skt. miś'wink', Lat. micāre 'twinkle'.

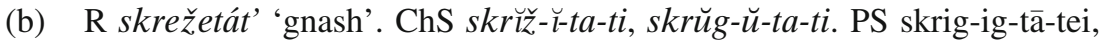
skrug-ug-tā-tei.

(c) R šeptát' 'whisper'. LCS šı̆p-r̆-ta-ti. PS sjip-ip-tā-tei.

(d) R ščebetát' 'twitter; chatter', ChS štǔbu-ta-ti. PS stjib-ib-tā-tei.

Of the RPs that appear to have been innovated in Slavic in the prehistorical period one is decidedly minor (11), but the other examples in (14)-(17) can be viewed as phonologically conditioned variants of a single, well-developed pattern, whose lexical frequency gives evidence of its former viability. It is interesting because of the fact that it may exemplify the full trajectory from total reduplication to loss ( 1 . ROOT + ROOT-tā- $>$ 3. ROOT + VC-tā- $>$ 4. ROOT + V-ta- $>$ 5. ROOT-Vta-). Here Stage 
5 results from a dissociation of the ertstwhile echo vowel from the root and its assignment to the suffix LCS -ota-, which occurs in other verbs. This disassociation may have affected different lexemes at different times, cf. PS stjek-ek-t-a-a $->$ stjekatā- > LCS šček-ota-, R šček-ota-t' 'tickle' or (15.d) PS xrep-ep-tā-tei, LCS xrepe-ta-ti, R d. xrep-ota-t' (Vaillant 1966, pp. 340-344).

\section{Renewal in Baltic}

Renewed RPs in Baltic can be observed in three areas of morphology: the formation of roots (Sect. 4.1); several minor patterns of prefixed stem formation expressing intensive or attenuative modification (Sect. 4.2); and the diverse patterns associated with 'eventives', predicative words that may accompany or substitute for verbs (Sect. 4.3). Eventives occur singly, iterated, and with a variety of stem modifications including reduplication. They are significant as a para-lexical sign reservoir which may be the source of innovated RPs with lexical or grammatical content.

\subsection{Reduplicative root formation}

Both Baltic and Slavic evidence two types of reduplicative roots that appear to have existed since Indo-European times, but may have been formed continually or repeatedly in the past, a $\mathrm{C}_{1} \mathrm{VC}_{1}-$ type and a $\mathrm{C}_{1} \mathrm{VR}-\mathrm{C}_{1}$ - type. In each of the language groups these are instantiated with language-specific examples, most clearly observable in Lithuanian.

As can be seen in (18), (19), the $\mathrm{C}_{1} \mathrm{VC}_{1}$ - type comprises nursery words and onomatopoeia.

(18) Nouns. (a) Li. bob-a 'woman, wife', La. bãba.

(b) Li. dède 'uncle'.

(c) Li. bỹ bis 'penis', La. bĩbis.

(d) Li. gagónas 'gander', La. gâgans.

(e) Li. gugà 'hump, bump', La. gudzêt 'sit hunched'.

(f) Li. gugénti 'shiver', La. gugêet 'whine'. Etc.

(19) Verbs: (a) bébti 'bleat', La. bebinât 'chatter'.

(b) Li. dadénti, gagénti 'cackle'. Etc.

The more complex $\mathrm{C}_{1}$ VR- $\mathrm{C}_{1}$ - type has the appearance of a reduced, suffixed rhyme reduplication (Gamkrelidze and Ivanov 1984, p. 222). Characteristic of the lexemes of this type are those in which the initial part recognizably contains a PIE root, the reduplicated initial does not correspond to any PIE suffix, and derivation from an original total reduplication is semantically plausible, that is, the lexeme can be viewed as representing Stage 4. A good example is Li. vir- $v-\dot{e}$ 'string', whose first part can be identified as a reduced grade of PIE wer- 'turn', whose stem-final consonant cannot be assigned any separate content, and whose referents are produced by repeated twining. Nouns in (20), verbs in (21). 
(20) (a) Li. bámba 'navel, La. bamba 'ball', PB bam-b-ā-; cf. LCS popŭ 'navel', PS pampa- (contrast La. naba, OPr. nabis, PIE $\mathrm{h}_{3}$ nob $^{\mathrm{h}}$-).

(b) Li. bùlbe 'potato', La. bulbe, PB bul-b-ē- .

(c) Li. gargaras 'nag'.

(d) Li. virvè 'string', PB wir-w-iā-, pre-PB wir-wir-? PIE wer- 'turn, twist'.

(21) (a) Li. bambèti 'grumble', Li. barbèti 'jingle', barbùtè 'ladybug'.

(b) Li. birbti 'humm', La. birbinât.

(c) Li. dardeti 'gabble'.

(d) Li. dindèti 'clang', La. dindêt.

(e) Li. dundeti 'boom, thunder'.

(f) Li. murmeti 'mumble'. Etc.

(g) Li. varveti 'drip, fall in drops', PB war-w-ē-, pre-PB war-war-? PIE wer- 'water'.

\subsection{Lexicalized RPs}

\subsection{1 $C_{1} V_{X^{-}} \check{c}-:$ intensives}

The first of the three minor patterns to be mentioned here consists of a prefixed $\mathrm{CV}_{\mathrm{x}^{-}}$ reduplication and an interfixed $-\check{c}$-, which together form a CVC prefix. The $\mathrm{V}_{\mathrm{x}}$ is a high vowel, front or back in harmony with that of the root. The $-\check{c}$ - interfix stands out phonotactically; /č/ occurs regularly before vowels in the inherited lexicon, but before consonants only in neologisms. There is only a handful of tokens of this RP, which forms adjectives and adverbs. Its content is Intensive (Otrębski 1965, p. 3).

(22) (a) vi-č-vien-as 'all alone' adj. ( $\leftarrow$ vien-as 'one, alone').

(b) pi-č-piln-is 'brim-full' adj. ( $\leftarrow$ piln-as 'full').

(c) tù-č-tuojau 'right away' adv. ( $\leftarrow$ tuojaũ 'immediately').

(d) tù-č-toks 'just such' adj. ( $\leftarrow$ tõks 'such').

\subsection{2 $C_{1} V_{1} C_{2^{-}}$: elative adjectives}

In the Eastern High Lithuanian dialect of Latakiškè a few tokens exemplify a local RP signifying 'attenuated elative' (Otrębski 1965, p. 2); see (23).
(a) pil-piln-ỹtel-is 'pretty full' adj. ( $\leftarrow$ pilnas 'full').
(b) sau-saus-ỹtel-is 'good and dry' adj. ( $\leftarrow$ saũsas 'dry').

\subsection{3 $C_{1} V_{X} C_{2^{-}}:$intensive nouns}

Standard Lithuanian has a minor RP forming Intensive nouns. Reduplicant and root contrast (morphophonemically) short and long vowels (Otrębski 1965, p. 2). 
(24) (a) gér-gèr-is 'the best part' n. ( $\leftarrow$ gẽras 'good').

(b) mãg-mog-is 'amusement' n. ( $\leftarrow$ magéti-mãga 'to desire').

(c) mãž-mož-is 'trifle' n. ( $\leftarrow$ mãžas 'small').

(d) skán-skon-is 'dainty' n. ( $\leftarrow$ skanùs 'tasty').

(e) niẽk-niek-is 'trifle' n. ( $\leftarrow$ niẽkas 'nothing').

\subsubsection{Root-reduplication}

Finally, the standard language has a few lexemes formed with root reduplication. The adverbs (a)-(c) are case forms (ins.pl.) of nouns that are not current; this is true also of (c), which is not a wordform of priě̌-prieš- $\grave{a}$ 'opposite' (Otrębski 1965, p. 2).

(25) (a) kart-kart-émis, kart-karč-iais adv. 'from time to time' ( $\leftarrow$ kart-as 'time').

(b) kryž-kryž-aĩs 'criss-crossing' adv. ( $\leftarrow$ krỹži-us 'cross').

(c) príeš-prieš-ais 'across from each other' adv.; prieš-prieš-à $\mathrm{n}$. 'opposite' ( $\leftarrow$ príeš 'before').

\subsection{Eventives}

Eventives are a Lithuanian part of speech that represents events, a characteristic captured by the native term Li. ištiktùkai 'eventives' (cf. ištikti 'occur'). Although uninflected, eventives may be conjoined with finite verbs or function as finite verbs. In the former case, the eventive presents a prominent feature of the situation the verb represents; in the latter case, the eventive represents an activity or action and may be intransitive or transitive. In grammars of Lithuanian eventives are sometimes considered a kind of interjections (cf. Senn 1966, p. 308), but unlike interjections they serve to describe or represent situations. Sometimes they are called onomatopoeia (cf. Leskien 1902/1903; Ambrazas 1997, p. 440). It is true that many eventives are clearly onomatopoeic, but as will be seen below (Sect. 4.3.3), this is not really a defining feature of eventives as a part of speech.

Eventives are usually given rather short shrift in standard grammars (Otrębski 1956, p. 373; Senn 1966, p. 308). An early, probably the first, specialized treatment is Leskien (1902/1903). The exposition that follows is based on the description in Jašinskaite (1971). Ambrazas (1997, pp. 440-448) offers a briefer, glossed account.

\subsubsection{Content}

Eventives typically represent predicates with the following semantic characteristics:

(26) (A) The sounds of insects, birds, or animals or

(B) the sound, sight, and/or sensation

(1.a) of physical phenomena in the environment (e.g. running water, rain, thunder, wind, leaves, fire, light) or 
(1.b) human-made devices (e.g. mechanisms, machines, instruments); or

(2) of locomotion (e.g. walking, running, jumping, tumbling) or movements (e.g. striking, cutting, breaking, grabbing, stabbing); or

(3) of physiological activities and events (e.g. speaking, eating, swallowing, weeping, coughing, snoring, glancing, side-stitch, heart-beat, expiring); or

(C) of mental experiences (e.g. recall, realization) and evaluations, including the suddenness of an event, its casualness, or non-existent outcome.

\subsubsection{Content syntax}

As mentioned above, the sentence-syntactic functions of eventives vary. Regardless of its morphological make-up, an eventive can be the equivalent of a clause (27) or serve as a finite verb, transitive (28) or intransitive (29).

Motoras tik pur-pur-pur, žlẽkt-plẽkšt ir sugedo engine just $[---], \quad[--]$ and PF.die.PST.3

'The engine just [went putt-putt-putt], [sputtered], and died.'

(28) duris.ACC tràkš! tràkš! ant rakto door on key 'he locked the door with two turns of the key'

(29) lietus tik žár-žár i langa rain just [- $]$ onto window 'the rain just kept coming down in sheets against the window pane'

Very commonly, a verb-equivalent eventive is preposed to and conjoined with a finite verb, either transitive (30) or intransitive (31). In such combinations, the eventive typically presents some salient aspect of the situation represented by the verb. But there are also 'true' conjunctions of eventive and finite verb, where the eventive represents a situation distinct from that of the finite verb, such as (27) (with its two clausal eventives) and (32) (where the eventive predicate is modified by a time adverbial).

(30) $\quad$ džigu-ď̌àgu ir perpiové atvarslus. ACC.PL arkliui.DAT $[--] \quad$ and slashed the reins of the horse;

'[with two cuts] he slashed the reins of the horse'

(31) buburgt ir panèré

[flop] and dove in

'he dove in with a flop' 


$$
\begin{aligned}
& \text { tik tèkšt-tebelèkšt } \\
& \text { just }[--]
\end{aligned} \begin{gathered}
\text { valanda } \\
\text { hour.ACC }
\end{gathered} \begin{gathered}
\text { ir busi and be.Fut.2sG after wedding } \\
\text { 'they just snap their fingers for an hour and you are done with the wedding' }
\end{gathered}
$$

Finally, eventives may serve an adverbial function, mostly immediately preceding a finite verb (34), again serving to illustrate some aspect of the finite verb event.

$$
\begin{aligned}
& \text { Kurnì-kurni béga šunelis. } \\
& \text { [--] run.PRs.3 dog.DIM }
\end{aligned}
$$

\subsubsection{Expression}

Eventive expressions fall into two categories, (1) deverbal and (2) imitative.

A full description of eventive expressions is unnecessary for present purposes and in any case cannot be given; even that of Jašinskaite (1971), despite its rich exemplification, is not exhaustive.

There are five sources of incompleteness. (i) Attestation in print media provides a limited picture of the actual richness of spoken usage. (ii) Spoken usage is open to a greater degree of creativity than the rest of the lexicon. (iii) There is considerable geographical variation in usage both in general text frequency and in syntactic feedom: eventives are more frequent and varied in Lowland (northwestern) and eastern Upland dialects, and it is mainly in these (peripheral) areas that they occur as predicates; see Zinkevičius (1966, p. 443). (iv) There is some, perhaps considerable, diachronic variation (see Jašinskaite 1971, p. 736; Ambrazas 1997, p. 442); a comparison with the nineteenth-century attestation (the sources of Leskien 1902/ 1903) would be useful. (v) There is presumably a degree of personal variation. One or several of these factors would account for the evident synonymy of eventives that is documented in the published descriptions; cf. (46), (47) below.

(1) Deverbal eventives are formed from a lexical verb root, optionally modified with vowel apophony and/or with a consonant or vowel suffix; e.g. traũ $k-t i$ 'pull' $\rightarrow$ trùk-t, brazd-é-ti 'scratch, scrape' $\rightarrow$ brazd-ù, kurn-é-ti 'run' $\rightarrow$ kurn- $\tilde{y}$.

(2) Imitative eventives are built from canonical root shapes, (C) (C) CVC(C), optionally expanded with the addition of $-\check{s}$ or $-s$ and/or $-t$; e.g. bàk, bàk- $\breve{s}, b a ̀ k-s$,

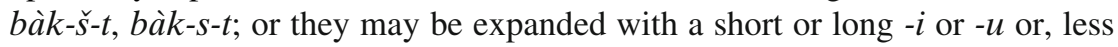
commonly, another vowel or a vowel + sonorant sequence.

\subsubsection{Expression syntax (morphosyntax)}

The expressions of eventives may occur singly or iterated (37). Either way they are subject to several kinds of morphological modification. These may be applied to single eventives or, more commonly, to the second constituent in an iteration.

In reduplication (34) the reduplicant vowel is short regardless of the quantity of the stem vowel, that is, a morphophonemically short stem vowel is copied as a short 
vowel, but so are the morphophonemically long /e:/ and /o:/, which are copied as, respectively, /e/ and /a/, and diphthongs, which are represented by their first segment; see (34) and note the variation in initial consonant clusters (e.g. žvi-žvilgt but di-drýkt).

But reduplication has to be seen in relation to the other kinds of modification (35), which in part exhibit a fair amount of variation: (i) internal stem extension, that is, infixing of a number of conventional $-\mathrm{C}_{\mathrm{x}} \mathrm{V}_{1}-$ or $-\mathrm{C}_{\mathrm{x}} \mathrm{V}_{1} \mathrm{C}_{\mathrm{y}} \mathrm{V}_{1}$ - elements (35.a); (ii) (variable) nucleus apophony (35.b), (iii) (variable) onset apophony (35.c), (iv) (variable) coda apophony (35.d), combinations of these (35.e), or prefixation with pa- 'perfective' (36).

(a) Short-vowel nucleus, $\mathrm{C}_{1}\left(\mathrm{C}_{2}\right) \mathrm{V}_{1^{-}}:$bàkšt $\rightarrow$ ba-bàkšt, žvilgt $\rightarrow$ žvi-žvilgt.

(b) Long-vowel nucleus, $\mathrm{C}_{1}\left(\mathrm{C}_{2}\right) \mathrm{V}_{1^{-}}:$bókšt $\rightarrow$ ba-bókšt, répšt $\rightarrow$ re-répšt, drýkt $\rightarrow$ di-drýkt.

(c) Diphthongal nucleus, $\mathrm{C}_{1}\left(\mathrm{C}_{2}\right) \mathrm{V}_{1}-$ : kleîkt $\rightarrow$ kle-kleĩkt, ruĩst $\rightarrow$ ru-ruĩst.

(d) Triplication, $\mathrm{C}_{1}\left(\mathrm{C}_{2}\right) \mathrm{V}_{1}-$ : tvisk $\rightarrow$ tvi-tvi-tvisk.

(35) (a) Infixed stem extension. $-\mathrm{C}_{\mathrm{x}} \mathrm{V}_{1^{-}}: c i \tilde{n} \rightarrow c i\langle l i\rangle \tilde{n}$, càp $\rightarrow c a\langle r a ̀\rangle p$;

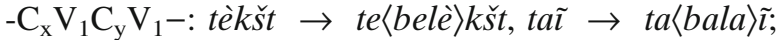

(b) Variable vowel apophony, e.g. $i-a$ in $d \check{z} \grave{i g u-d z ̌ a ̀ g u ; ~ a l s o ~} i-e i, i-u$, $y-o, y-\tilde{e}, y-a u, u-\tilde{a}, \dot{e}-o, e-a \ldots$;

(c) Variable onset apophony, e.g. $d z^{\prime}-b r^{\prime}$ in $d z ̌ i n g t$-bringt; also $c-l$, $\check{c}^{\prime}-v^{\prime}, d z^{\prime}-b r^{\prime}, d z^{\prime}-l$ ', $p l$ '- $\check{c}^{\prime}, s-b, \check{s}-m, \check{s}^{\prime} l^{\prime}-t r^{\prime}, t-m, t r-p, z l^{\prime}-p l ' \ldots$;

(d) Variable coda apophony, e.g. $k t-k \check{s} t, k \check{s}-k \check{s} t, n-p \ldots$;

(e) Combinations of these, e.g. klañk-kli-klañk, žlẽkt-plẽkšt, pùkš $-p a u\langle t \grave{u}\rangle k \check{s}$.

(36) Prefixation with $p a$ - 'Perfective'.

(37) (a) One iteration. E.g. trakš! trakš! (42), pa-drùmst pa-drùmst (54).

(b) Extended iteration. E.g. talam-talam-talam; cf. (40), (41), (44).

(c) Iteration with infixed stem extension. E.g. ciñ-ciliñ (51), tèkšt-tebelèkšt (52).

(d) Iteration with vowel apophony. E.g. džigu-džàgu (53).

(e) Iteration with consonant apophony. E.g. žlẽkt-plẽkšt (39).

\subsubsection{Iconicity: content and expression}

Iconicity concerns the relation between an expression and its content-in Peircean terms, between a sign and its object. In Peirce's theory of semeiotic, an icon acts as a sign by virtue of a similarity between the sign (expression) and its object (content). Peirce distinguishes three varieties of iconic relations, (i) an image depicts its object by means of a similarity in simple qualities; (ii) a diagram reflects its object by 
means of a similarity between the relations of its elements and those of its object's; and (iii) a metaphor suggests its object by means of a parallelism with another sign and its object; cf. Nöth (1990, pp. 121-133).

Although iconicity concerns the relation between content and expression, it is possible to consider content and expression one by one.

As for their content, it was stated in (26) that eventives represent a variety of content categories or semantic fields. Now, when the speech sounds of eventive expressions represent auditory phenomena (26.A-B), they can be more or less imaginal. But when speech sounds represent phenomena from other experiential domains than sounds (26.B-C), imaginal relations are excluded; such signs are either iconic thanks to a parallelism (or association) between different domains of experience-which may allow onomatopoeia to represent visual phenomena-that is, they are metaphors (in Peirce's sense); or they are non-iconic.

As for expressions, the simplest kind of iconicity is the imaginal depiction of sounds. Such a depiction can either illustrate a verbal account of the depicted event as in (38) (dziuñ 'whizzed by', dziàp 'hit the ground') or it can directly represent audible events, unaccompanied by any verbal explication as in (39), with its $r$ diphthongs and simple nuclei followed by increasingly consonant-heavy onsets and codas. In terms of Peirce's three-way distinction of icons into (i) images, (ii) diagrams, and (iii) metaphors, these are predominantly imaginal icons, but the sequence of their parts forms a diagram of the sequence of auditory events. And to the extent such depictions are limited by the phoneme inventory of the language, they rely on more or less ad hoc conventions for matching up the referent sounds with similar phoneme shapes, that is, they are somewhat metaphoric (in Peirce's sense).

$\begin{array}{ll}\frac{\text { Dziuñ-dziàp! }}{[--]} & \begin{array}{l}\text { suzvembé kulka, } \\ \text { PF.whizz.PST.3 bullet, }\end{array} \text { and PF.knock.PTCP from ground } \\ \text { dulkes, parodè } & \text { vietą kur } \quad \text { pakliudè. }\end{array}$

dust, PF.find.PST.3 place where PF.rest.PST.3

'[- - ] A bullet whizzed by, knocked some dust up from the ground and found a place where it came to rest.'

\section{Motoras tik pur-pur-pur, žlékt-plékšt ir sugedo engine just $[---], \quad[--] \quad$ and PF.die.PST.3 \\ 'The engine just [went putt-putt-putt] [sputtered] and died.'}

Imaginal representations of sounds by like sounds are seen in (40), where long high front vowels represent the twitter of sparrows; and in (41), where short high back vowels represent the muffled sounds of a beating heart. In (42) short open vowels depict the smart sounds of a key turned twice in a lock, while long open vowels represent the persistent sound of rain against a window pane (43), and iambic disyllables represent the repeated strokes of a strickle against the blade of a scythe (44).

$\underline{c} \tilde{y} v-\check{c} \tilde{y} v-$ suriko žvirbliai.

[tweet-tweet] shriek.PST.3 sparrows

'[tweet, tweet] went the sparrows.' 
(41) Tùk-tùk-tùk-tùk plakè apmirusioje merginos kutineje širdis.

[-- - ] beat weakened.LOC girl.GEN chest.LOC heart.NOM

'The heart beat [fast] in the young girl's enfeebled chest.'

(42) Tuojau sūnus vyresnis išeina nuo tèvo, duris tràkš! tràkš! ant rakto. immediately son elder exit.PRS.3 from father, door.ACC [-] on key

'The moment the elder son comes out from the father's room, he [locks] the door, [turning the key twice].'

(43) Lietus tik žár-žár i langą, matau, kad jau nevažuosim. rain just $[--]$ on window, see.PST.1SG that now not.depart.FUT.1PL 'The rain just [kept coming down in sheets] against the window pane, I realized that now we wouldn't be leaving.'

(44) Talam-talam-talam émé tamsoje galasti dalgi vaiduoklis. [--] took.PST.3 dark.LOC sharpen.INF scythe apparition 'In the dark the apparition began to sharpen its scythe [stroke after stroke].

In each of these eventives, one can observe different degrees of iconicity in the number of iterations. (42) tells us the key turned twice in the lock. But the extended iterations in (41) and (44) do not represent the number of heart beats or strickle strokes, but are ad hoc metaphors signifying numerous identical event parts. In (40) and (43), too, the single iteration is not to be understood as representing a single repetition, but as a common metaphor for multiple events or event parts.

When eventives do not represent sound, they are not imaginal, but fully metaphoric transfers from one experiential domain to another (45). A clear indication of this relative 'arbitrariness' is the degree of synonymy that can be observed in usage; compare (46) and (47). But these metaphors (46), (47) continue to be supported, probably, by the vaguely imaginal onset apophony in (46) and the diagrammatic elements of internal reduplication in (47).

Similarly, in the deverbal eventives, the segments and quantity of suffixes carry some imaginal content, as in (48), where the long final vowels suggest speed, and (49), where the short final vowels are suggestive of the little dog's rapid gait. Note here the etymological figure of kurnỹ with nukurnejo in (48) in contrast to (49), where the verb is the generic be ga.

Šár-šár ir padirbo.

[--] and PF.work.PST.3

'[one-two-three] he was done.'

(46) Nedirbi, kad būtu gerai, o kaip pakliūva-sùrum-bùrum. not.work.PRs.3, that be.sUBJ.3 well, but anyhow.IDIOM [- ] 'He doesn't work to do anything well, but any old way [slap-dash].' 
Jis tik tabalã̃-tabalaĩ padirbo, bet nežiūri kaip gerai. he just [- $] \quad$ PF.work.PST.3, but not.look.PRS.3 how well 'He just worked [so-so], but he doesn't pay attention how to do it well.'

(48) Vaikas kurnỹ $-\underline{k u r n \tilde{y}}$ ir nukurnejjo.

child $[--]$ and PF.run.PST.3

'The kid scurried off [as fast as he could].'

\section{(49) Kurni-kurnì bèga šunelis.}

[--] run.PRS.3 dog.DIM

'The little dog runs [as fast as it can].'

Reduplication and infixation may both be imaginal, as in (50), where the reduplicated eventive depicts the twin sounds often produced by a dive, and in (51), which depicts first the impact and then the shattering of a glass. The eventive in (52) is perhaps mainly metaphorical; the combined iteration and internal stem expansion diagram the diverse activities posited as parts of a wedding ceremony, but the $-b V_{1} l V_{1}$ - shape of the infix metaphorically suggests the supposed casualness of the ceremony.

Apophony as well typically adds iconic elements to iterated eventives. While the iterated eventives in (53) depict the sounds of the knife, the apophony is metaphorical and suggests the different directions of the movements made to slash the reins.

(50) Šoko nuo skardžio ì vandeni, buburgt ir panère.

jump.PST.3 from bank into water, $[--]$ and PF.dive.PST.3

'He took off from the bank and dove into the water [with a flop].'

(51) Stikliukas $\underline{\text { ciñn-ciliñ }}$ ant akmens ir subyrëjo.

glass $[--]$ on stone and shattered

'The glass fell against the stone and shattered [- - .'

(52) Ar manai, kad tik tèkšt-tebelèkšt valandąir busi po vestuvių?

Q think.PRs.2 that just [- - ] hour.ACC and be.FUT.2sG after wedding

'Do you think they just snap their fingers for an hour and you are done with the wedding?'

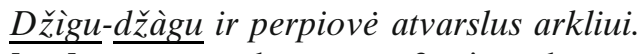

[- - ] and PF.cut.PST.3 reins horse.DAT

'[With two cuts] he slashed the reins of the horse.'

Non-auditorily-based eventives use the same morphological devices as auditorilybased ones; e.g. kyšt 'was aflame', bli-bli-bli 'was smouldering', pakabakš-pakabaǩ̌ 'hobbled along'. Non-sensorily-based eventives are perhaps mainly deverbal; e.g. grabi grabi 'was groping in the dark'; see also (48), (49), above. But 
many exploit the synaesthetic (metaphoric) associations to the sensory realms; $\mathrm{cf}$. (46), (47), (52), (59).

\subsection{Grammatical features: iteration and verbal aspect}

Since eventives are not inflected, they are indifferent with regard to person and number as well as to tense. In most of the examples above, the eventives occur in past-tense contexts; in a few, they are equivalent to present-tense verbs (42), (59); and in one, to a future (52).

There is only a weak correlation between eventive iteration and aspect. I assume a basic three-way division of situations into states, activities and actions; the latter can be conceptualized as processes or as events. Viewed in these terms, iterated eventives represent either an activity or a process (imperfective equivalent): (39)(41), (43), (49); or a composite event (perfective equivalent): (42), (45), (48); the latter is typically the case when an eventive is reduplicated (50) or an iteration includes an infixed stem extension (47), (51), (52), apophony (53), or prefixation (54).

Eventives with the prefix $p a$ - are perfective; but also without the prefix, simple eventives are mostly equivalent to a perfective verb; see the actions in (55), (56), activities in (57)-(59).

(54) Varlès padrùmst padrùmst ir sušoko i vandenị. frogs $[--]$ and jump.PST.3 in water '[one after another] the frogs jumped into the water.'

(55) Diedas dràk bobai pagaliu per galvą uncle [-] woman club.INSTR on head 'Uncle [banged] the woman on the head with the club.'

(56) Kriókšt ir perdūré su šake siršių lizdą. [-] and knock.PST.3 with branch hornets' nest 'S/he whacked the hornets' nest down with the hay-fork.'

(57) Burbt suburbé plaukuose isivèlusi bité. [-] PF.buzz.PST.3 hair.LOC entangled.PTCP bee

'There was a buzzing of a bee that had got caught in [her] hair.'

(58) Tik biziñgt vambole pro šali and $[-]$ beetle past side 'A beetle buzzed by.'

(59) Namišiai virstuveje pavalgi, o mudviem - šmikšt. dwellers kitchen.LOC PF.eat.PRs.3, but we-two.DAT [-] 'The household get dinner in the kitchen, but for the two of us-nothing.' 


\section{Conclusion: loss and renewal}

Neither Slavic nor Baltic languages make systematic, obligatory use of RPs in either derivation or inflection in the modern period.

Both language groups have lost the RPs that can be reconstructed for PIE and show only faint traces of them (Sect. 2). There are more traces in nouns, where RPs served the formation of stems, than in verbs, where the inherited RPs had developed into merely ancillary morphophonemic devices already by PIE (Sect. 2.3).

But both language groups have developed new RPs.

These have largely been lost again in Slavic in part due to the phonotactic restructurings produced by the sweeping sound changes that occurred in Common Slavic on the eve of the historical period (Sect. 3).

But Lithuanian has a few minor, lexicalized RPs (Sect. 4.2) and, additionally, a part of speech, the eventives, in which iteration, reduplication, infixation, and apophony are used to form iconic representations of sensory and other experiential dimensions of states, activities and actions (Sect. 4.3-4.4).

One of the most striking features of the eventives is the considerable variability of their expressions, including the several kinds of infixation and, especially, the highly variable apophonic relations in nuclei, onsets, and codas. It is apparent that the expressions of eventives are subject to rather fluid, perhaps in part local, norms, but on the whole have not been firmly codified and are open to individual innovation.

It seems a reasonable guess that it is from a pool of such expressions that the minor, lexicalized RPs in Sect. 4.2 have arisen.

One may well wonder how long eventives and their various expressive devices have been in existence in the language. This cannot be established with certainty. The way long stem vowels are copied in reduplication (bokšt $\rightarrow$ ba-bokšt) (Sect. 4.3.4) suggests that at least reduplication was well established prior to the vowel shift that occurred in much of the Lithuanian language area before 1550 (in which *ba-bākšt $>b a-b o k s ̌ t)$. Had they been established later, there might not have been any qualitative difference between base vowel and reduplicant vowel. But this little piece of relative chronology does not shed much light on the age of eventives. Leskien (1902/1903, p. 166) draws attention to a number of Lithuanian eventives that have precise correspondences in Latvian and concludes that the category may be ancient.

Whatever their age, the Lithuanian eventives remain highly interesting from a synchronic and typological point of view. By their flexible part of speech status, by the great variety of morphological processes they employ, and by their openness to creative innovation they are perhaps unique among the languages of Europe. But in the wider world of languages eventives may be a common, paralexical fund of expressions. And wherever they are found they may form the natural background for the creation of new patterns of morphological expression including patterns of reduplication.

Open Access This article is distributed under the terms of the Creative Commons Attribution Noncommercial License which permits any noncommercial use, distribution, and reproduction in any medium, provided the original author(s) and source are credited. 


\section{References}

Ambrazas, V. (Ed.). (1997). Lithuanian grammar. Vilnius: Baltos Lankos.

Andersen, H. (1986). Protoslavic and common Slavic: Questions of periodization and terminology, Slavic Linguistics, Poetics, Cultural History. In M. S. Flier \& D. S. Worth (Eds.), In Honor of Henrik Birnbaum on his Sixtieth Birthday, 13 December 1985 (= International Journal of Slavic Linguistics and Poetics 31/32), (pp. 67-82). Columbus, OH: Slavica Publishers.

Andersen, H. (1993/1998). Le lingue slave. In P. Ramat \& A. Giacalone-Ramat (Eds.), Le lingue indoeuropee (pp. 441-480). Bologna: Il Mulino. English version: "[Chapter] 14. Slavic". In P. Ramat \& A. Giacalone-Ramat (Eds.), The Indo-European Languages (pp. 415-453). London; New York: Routledge.

Fraenkel, E. (1962-1965). Litauisches etymologisches Wörterbuch (Vols. 1-2). Heidelberg: Carl Winter Universitätsverlag \& Göttingen: Vandenhoeck and Ruprecht.

Gamkrelidze, T. V., \& Ivanov, V. V. (1984). Indoevropejskij jazyk i indoevropejcy. Rekonstrukcija $i$ istoriko-tipologičeskij analiz prajazyka i protokul'tury (Vols. 1-2). Tbilisi: Izdatel'stvo tbilisskogo universiteta.

Hurch, B., \& Mattes V. (2005). Ueber die Entstehung von partieller Reduplikation. In G. Fenk-Oczlon \& C. Winkler (Eds.), Sprache und Natürlichkeit. Gedenkband für Willi Mayerthaler (pp. 137-156). Tübingen: Narr.

Jašinskaite, J. (1971). Ištiktukai. In V. Ambrazas (Ed.), Lietuvių kalbos gramatika (Vol. 2). Morfologija (pp. 734-746). Vilnius: Mintis.

Kulikov, L. I. (2005). Reduplication in the Vedic verb: Indo-European inheritance, analogy and iconicity. In B. Hurch (Ed.), with editorial assistance of V. Mattes, Studies on reduplication. Empirical approaches to language typology, 28 (pp. 431-454). Berlin/New York: Mouton de Gruyter.

Leskien, A. (1902/1903). Schallnachahmungen und Schallverba im Litauischen. Indogermanische Forschungen, 13, 165-212.

Nöth, W. (1990). Handbook of semiotics. Bloomington/Indianapolis: Indiana University Press.

Otrębski, J. (1956). Gramatyka języka litewskiego (Vol. 3). Nauka o formach. Warszawa: Państwowe Wydawnictwo Naukowe.

Rasmussen, J. E. (1984/1988). The make-up of Indo-European morphology. Arbejdspapirer fra Institut for Lingvistik, Københavns Universitet, 4, 119-133. Also in Diachronica, 4, 107-122 (1988).

Rasmussen, J. E. (1997). Processes of grammaticalization in Indo-European verbal morphology. In A. Lubotsky (Ed.), Sound law and analogy. Papers in honor of Robert S. P. Beekes on the occasion of his 60th birthday (pp. 249-262). Amsterdam: Rodopi.

Senn, A. (1966). Handbuch der litauischen Sprache (Vol. 1). Grammatik. Heidelberg: Carl Winter Universitätsverlag.

Stang, C. S. (1966). Vergleichende Grammatik der Baltischen Sprachen. Oslo/Bergen/Tromsø: Universitetsforlaget.

Trubačev, O. N. (1973-). Ètimologičeskij slovar' slavjanskix jazykov. Praslavjanskij leksičeskij fond [Etymological Dictionary of the Slavic Languages. The Proto-Slavic Lexical Stock] (Vols. 1-.) Moskva: Nauka.

Vaillant, A. (1966). Grammaire comparée des langues slaves (Vol. 3, parts 1-2). Le verbe. Paris: Klincksieck.

Vasmer, M. (1953-1957). Russisches etymologisches Wörterbuch (Vols. 1-3). Heidelberg: Carl Winter Universitätsverlag.

Zinkevičius, Z. (1966). Lietuvių dialektologija. Lyginamoji tarmiụ fonetika ir morfologija (su 75 žemèlapiais). Vilnius: Mintis. 